Jurnal Ilmu Dan Teknologi Kesehatan

Vol 7, No 1, September 2019,

ISSN: 2338-9095 (Print)

ISSN: 2338-9109 (online)

\title{
Efikasi Diri Berhubungan dengan Kepatuhan Manajemen Diri pada Pasien Diabetes Melitus di Wilayah Kerja Puskesmas Buleleng III
}

\author{
Ni Komang Desi Tri Handayani, Putu Wira Kusuma Putra, Ida Ayu Agung Laksmi \\ STIKES Bina Usada Bali \\ E-mail: tdesi485@yahoo.com
}

\author{
Artikel history \\ Dikirim, Jun $12^{\text {th }}, 2019$ \\ Ditinjau, Jul $12^{\text {th }}, 2019$ \\ Diterima, Sept $5^{\text {th }}, 2019$
}

\begin{abstract}
Diabetes mellitus is a group of metabolic diseases with characteristics of hyperglycemia that occur due to abnormal insulin secretion and insulin performance. Prevention of the occurrence of DM complications can be done by obediently doing good self-management behavior. Self-management compliance of good diabetes mellitus can achieve success if individuals have the knowledge, skill, and self-efficacy to manage diabetes mellitus. Selfefficacy determines how a person feels, thinks, motivates himself, and behaves from time to time. This study aimed to determine the correlation between self-efficacy and selfmanagement compliance of diabetes mellitus patients. This study used the Cross-Sectional approach with a number of samples was 139 respondents. The sample selection used nonprobability sampling, especially purposive sampling. Data collection tools used questionnaires. Self-efficacy could be measured using the general self-efficacy questionnaire $(G S E)$ and self-management compliance could be measured using the DSMQ (Diabetes SelfManagement Questionnaire). Data analysis used Spearman Rank correlation analysis. The results obtained that $p$-value $0,0001(p<0,05)$, therefore it could be concluded that there was a correlation between self-efficacy and self-management compliance of diabetes mellitus patients. Researchers suggest that health care workers can help patients with diabetes mellitus in improving their self-efficacy by providing motivation and IEC regarding patients' self-management with diabetes mellitus.
\end{abstract}

Keywords: Diabetes Mellitus; Self Efficacy; Compliance; Self Management

\begin{abstract}
ABSTRAK
Diabetes Melitus merupakan suatu kelompok penyakit metabolik dengan karakteristik hiperglikemia yang terjadi karena kelainan sekresi insulin dan kinerja insulin. .Pencegahan terjadinya komplikasi DM dapat dilakukan dengan patuh melakukan prilaku manajemen diri yang baik. Kepatuhan manajemen diri diabetes melitus yang baik dapat mencapai keberhasilan jika individu memiliki pengetahuan, keterampilan dan efikasi diri untuk melakukan pengelolaan diabetes melitus. Efikasi diri menentukan bagaimana seseorang merasa, berpikir, memotivasi diri, dan berprilaku dari waktu ke waktu. Penelitian ini bertujuan untuk mengetahui hubungan efikasi diri dengan kepatuhan manajemen diri pada
\end{abstract}


pasien diabetes melitus. Penelitian ini menggunakan pendekatan Cross Sectional dengan jumlah sampel sebanyak 139 responden. Pemilihan sampel menggunakan nonprobality sampling khususnya purposive sampling. Alat pengumpulan data berupa kuisioner, pada Efikasi diri dapat diukur menggunakan kuesioner general self efficacy (GSE) dan kepatuhan manajemen diri dapat diukur menggunakan kuesioner The DSMQ (Diabetes SelfManagement Questionnaire). Analisis data menggunakan analisis kolerasi Spearman Rank. Hasil penelitian diperoleh $\mathrm{p}$-value $0,0001(\mathrm{p}<0,05)$, sehingga dapat disimpulkan bahwa ada hubungan efikasi diri dengan kepatuhan manajemen diri pada pasien diabetes melitus. Peneliti menyarankan agar petugas pelayanan kesehatan dapat membantu pasien diabetes mellitus dalam meningkatkan efikasi diri yang dimiliki dengan memberikan motivasi dan KIE mengenai manajemen diri pasien diabetes mellitus.

Kata kunci : Diabetes Mellitus; Efikasi Diri; Kepatuhan; Manajemen diri

\section{PENDAHULUAN}

Penyakit tidak menular (PTM) masih menjadi masalah kesehatan di dunia dan Indonesia yang salah satunya menjadi penyebab dari kematian. Salah satu jenis penyakit tidak menular (PTM) yaitu diabetes melitus. Diabetes Melitus merupakan suatu kelompok penyakit metabolik dengan karakteristik hiperglikemia yang terjadi karena kelainan sekresi insulin, kinerja insulin atau kedua duanya (ADA, 2010). Diabetes melitus telah menjadi salah satu penyakit degeneratif yang bila tidak ditangani dapat terjadinya komplikasi. Diabetes melitus sudah dianggap sebagai masalah yang serius dan memerlukan penanganan yang cukup serius. Berdasarkan data World Health Organization (WHO) 2015, ditemukan pada tahun 2015 kenaikan jumlah diabetes melitus di dunia mencapai 415 juta jiwa dan diperkirakan tahun 2040 jumlahnya akan menjadi 642 juta. Tahun
2015, Indonesia menempati peringkat ke tujuh di dunia untuk pravalensi penderita diabetes tertinggi di dunia. Prevalensi diabetes melitus dari 33 provinsi di Indonesia, khususnya di Bali tahun 2013 diperkirakan jumlah penderita DM mencapai 39.885 jiwa yang telah didiagnosa oleh dokter dan yang belum pernah didiagnosa oleh dokter yaitu 6.136 jiwa (Kemenkes RI, 2014).

Tingginya kejadian DM serta pola hidup yang tidak sehat tidak lepas dari masalah rendahnya kepatuhan pasien dalam manajemen diri DM. Manajemen diri merupakan kunci dalam penatalaksanaan penyakit kronis secara komprehensif (Atak, et al. 2010). Contoh ketidakpatuhan pasien dalam memanajemen diri yaitu tidak patuh pada program diet yang dianjurkan (International Diabetes Federation (IDF), 2015). Banyak pasien DM hanya 
mengurangi nasi dan makanan manis tanpa memperhatikan keteraturan jadwal makan, pemilihan jenis makanan, dan total kalori dalam satu hari sehingga kadar gula darah tinggi atau bahkan rendah (Al Tera, 2011).

Ketidakpatuhan diet menyebabkan buruknya kontrol gula darah dalam tubuh. Kontrol gula darah yang buruk secara langsung menyebabkan ketidakstabilan metabolisme dan hemodinamik tubuh (Dyson et all., 2011; Intercollegiate \& Network, 2013; (IDF), 2015). Ketidakpatuhan manajemen diri pada pasien DM dapat mengakibatkan terjadinya komplikasi seperti kerusakan saraf di kaki, meningkatnya risiko penyakit jantung dan stroke, serta terjadinya retinopati diabetikum. Pencegahan terjadinya komplikasi diabetes melitus dapat dilakukan dengan patuh melakukan prilaku manajemen diri yang baik.

Perilaku manajemen diri yang dapat dilakukan oleh penderita diabetes melitus adalah mengatur pola makanan, latihan fisik, pengobatan, pemantauan glukosa darah, perawatan kaki, dan berhenti merokok. Keberhasilan manajemen diri membutuhkan partisipasi aktif pasien, keluarga dan masyarakat. Kepatuhan manajemen diri diabetes melitus yang baik dapat mencapai keberhasilan jika individu memiliki pengetahuan, keterampilan dan efikasi diri untuk melakukan pengelolaan diabetes melitus. Efikasi diri menentukan bagaimana seseorang merasa, berpikir, memotivasi diri, dan berprilaku dari waktu ke waktu (Beckerle \& Lavin, 2013). Efikasi diri dapat menumbuhkan rasa percaya diri seseorang untuk mencapai hasil yang diinginkan. Penderita diabetes melitus harus memiliki keyakinan diri terhadap kondisi yang dialaminya serta segala terapi yang dianjurkan oleh tenaga kesehatan. Efikasi diri didefinisikan sebagai penilaian, kepercayaan atau keyakinan diri untuk mampu melakukan tugas-tugas tertentu, mengatur dan melaksanakan program tindakan yang diperlukan dalam mencapai tujuan yang diinginkan. Efikasi diri membantu seseorang dalam menentukan pilihan, usaha untuk maju, kegigihan dan ketekunan dalam mempertahankan tugastugasnya yang mencakup kehidupan mereka.

Penelitian yang dilakukan oleh Damayanti (2017) mengatakan bahwa self-efficasy enhanchement intervention program memberikan motivasi, konseling dan monitoring, sehingga membantu 
meningkatkan pengetahuan dan manajemen diri pasien diabetes melitus. "Hubungan antara Spiritualitas dan Efikasi Diri dengan Kepatuhan Pasien Diabetes Melitus Tipe 2" dari penelitian ini mengatakan efikasi diri merupakan prediktor utama dari perilaku yang dapat mempengaruhi dimulainya tugas, jumlah usaha yang dikeluarkan dalam melaksanakan tugas dan lamanya waktu orang tersebut akan memenuhi tugas (Damayanti, dkk., 2014). Peneliti Yaqin, dkk (2017) mengatakan bahwa dalam penelitiannya didapatkan ada efek self efficacy training pada kedua variabel dependen yang sangat bermakna, namun jika dilihat dari hasil selisih mean dengan kelompok kontrol, variabel kepatuhan memiliki peningkatan nilai mean yang lebih besar dibandingkan variabel Self Efficacy. Kesimpulan penelitian efek self efficacy training dapat meningkatkan kepatuhan diet pasien DM melalui peningkatan self efficacy. Hasil ini juga didukung oleh peneliti Hunt et al (2012) yang mengatakan bahwa efikasi diri memiliki hubungan yang positif dengan manajemen diri pasien diabetes mellitus.

Riset Kesehatan Dasar Provinsi Bali pada tahun 2013 mencatat bahwa Kabupaten Buleleng merupakan daerah kasus diabetes melitus tertinggi nomor dua di Bali, sekitar $1,0 \%$ pada daerah perkotaan sedangkan perdesaan sekitar 0,6\%. Berdasarkan studi pendahuluan yang dilakukan pada tanggal 3 November 2018 di Puskesmas Buleleng III dengan jumlah penderita diabetes melitus mencapai jumlah 219 kasus dalam tiga bulan terakhir. Diperkirakan 96 pasien diabetes melitus rutin melakukan cek kesehatan dan 123 pasien diabetes melitus tidak rutin melakukan cek kesehatan di Puskesmas Buleleng III. Data tersebut menunjukkan bahwa adanya ketidakpatuhan dalam manajemen diri pasien diabetes melitus di Wilayah Kerja Puskesmas Buleleng III.

\section{METODE}

Penelitian ini merupakan penelitian deskriptif korelasi dengan pendekatan Cross Sectional. Populasi penelitian ini adalah penderita DM tipe II di wilayah kerja Puskesmas Buleleng III. Jumlah sampel sebanyak 139 responden dengan teknik Sampel dipilih menggunakan nonprobability sampling khususnya purposive sampling. Responden yang dipilih berdasarkan kriteria inklusi dan ekslusi (Nursalam, 2013). Kriteria inklusi dalam penelitian ini adalah penderita yang bersedia menjadi responden, penderita dengan Diabetes Melitus tipe II, penderita yang tinggal dengan keluarga, dan penderita lansia berusia $\geq 60$ tahun. Kriteria eksklusi pada penelitian ini adalah 
penderita diabetes melitus tipe II yang tidak kooperatif, penderita diabetes melitus tipe II yang mengalami amputasi, penderita diabetes melitus tipe II yang mengalami luka gangrene. Variabel yang diteliti yaitu variabel efikasi diri dan variabel kepatuhan manajemen diri diabetes mellitus. Alat pengumpulan data berupa kuisioner, pada efikasi diri dapat diukur menggunakan kuesioner General Self Efficacy (GSE) dan kepatuhan manajemen diri dapat diukur menggunakan kuesioner The DSMQ (Diabetes Self-Management Questionnaire). Analisis data menggunakan analisis kolerasi Spearman Rank. General Self Efficacy (GSE) Kuesioner GSE pertama kali dibuat oleh Ralf Schwarzer dari Universitas Freie, Berlin. Skala Self Efficacy Ralf Schwarzer pertama kali dikembangkan pada tahun 1981 oleh Jarusalem dan Ralf Schwarzer, yang versi aslinya 20 item, kemudian setelah berkembang menjadi 10 item dengan respon format dari skor 1 sampai 4 (Smith et al, 2010). Efikasi diri dikategorikan menjadi: Efikasi diri tinggi skor: 30 - 40
Efikasi diri sedang skor: 20 - 29 Efikasi diri rendah skor: 10-19. Kuesioner The DSMQ (Diabetes Self-Management Questionnaire) yang telah dikembangkan di Lembaga Penelitian Diabetes Academy Mergentheim. DSMQ merupakan instrumen yang menargetkan perawatan diri diabetes, dan itu dirancang untuk menilai perilaku yang terkait dengan metabolisme kontrol dalam rejimen pengobatan umum untuk tipe 1 dan diabetes tipe 2. DSMQ mencakup manajemen glukosa,pengendalian diet, aktivitas fisik,dan penggunaan perawatan kesehatan. Satu item (16) secara keseluruhan terkait terhadap perawatan diri dimasukan dalam jumlah skala (Schmitt et al, 2013). Uji analisis yang digunakan pada penelitian ini adalah analisis kolerasi Spearman Rank. Kolerasi Spearman Rank digunakan untuk menguji signifikansi hipotesis asosiatif bila masing-masing variabel berbentuk ordinal dan sumber data antar variabel tidak harus sama (Arikunto, 2013). 


\section{HASIL DAN PEMBAHASAN}

Tabel 1. Karakteristik Responden Diabetes Melitus

\begin{tabular}{|c|c|c|}
\hline Data Demografi & Frekuensi & Presentase (\%) \\
\hline \multicolumn{3}{|l|}{ Usia } \\
\hline 60-65 tahun & 69 & 49,6 \\
\hline 66-70 tahun & 39 & 28,1 \\
\hline 71-75 tahun & 18 & 12,9 \\
\hline 76-80 tahun & 10 & 7,3 \\
\hline \multicolumn{3}{|l|}{ Pendidikan } \\
\hline SD & 40 & 28,8 \\
\hline SMP & 34 & 24,5 \\
\hline SMA & 53 & 38,1 \\
\hline Sarjana & 12 & 8,6 \\
\hline \multicolumn{3}{|l|}{ Pekerjaan } \\
\hline Tidak bekerja & 33 & 23,7 \\
\hline PNS & 3 & 2,2 \\
\hline Wiraswasta & 26 & 18,7 \\
\hline Petani & 77 & 55,4 \\
\hline \multicolumn{3}{|l|}{ Dukungan Keluarga } \\
\hline Mendapatkan dukungan keluarga & 131 & 94,2 \\
\hline Tidak mendapatkan dukungan & 8 & 5,8 \\
\hline keluarga & & \\
\hline \multicolumn{3}{|l|}{ Akomodasi } \\
\hline$<1 \mathrm{Km}$ & 112 & 80,6 \\
\hline$>1 \mathrm{Km}$ & 27 & 19,4 \\
\hline \multicolumn{3}{|l|}{ Kualitas Pelayanan } \\
\hline Puas & 129 & 92,8 \\
\hline Tidak puas & 10 & 7,2 \\
\hline
\end{tabular}

Karakteristik responden adalah sebagai berikut: $49,6 \%$ berusia $60-65$ tahun, $38,1 \%$ pendidikan terakhir SMA, 55,4\% berkerja sebagai petani $94,2 \%$ mendapatkan dukungan keluarga, 80,6\% Akomodasi atau akses menuju ke pelayanan kesehatan $<1 \quad \mathrm{~km} \quad$ (dekat),dan $\quad 92,8 \% \quad$ kualitas pelayanan puas (Tabel 1).

Tabel 2. Tingkat Efikasi Diri Pasien Diabetes Melitus

\begin{tabular}{lcc}
\hline \multicolumn{1}{c}{ Efikasi Diri } & Frekuensi & Presentase (\%) \\
\hline Efikasi Diri Tinggi & 43 & 30,9 \\
Efikasi Diri Sedang & 52 & 37,4 \\
Efikasi Diri Rendah & 44 & 31,7 \\
\hline
\end{tabular}

Tingkat efikasi diri pasien diabetes mellitus lebih banyak berada pada kategori sedang, yaitu sebanyak 52 orang atau 37,4\% (Tabel 2). 
Tabel 3. Tingkat Kepatuhan Manajemen Diri Pasien Diabetes Melitus

\begin{tabular}{lcc}
\hline \multicolumn{1}{c}{ Kepatuhan Manajemen Diri } & Frekuensi & Presentase (\%) \\
\hline Patuh & 59 & 42,5 \\
Kurang Patuh & 38 & 27,3 \\
Tidak Patuh & 42 & 30,3 \\
\hline
\end{tabular}

Tingkat kepatuhan manajemen diri pasien kategori patuh, yaitu sebanyak 59 orang atau diabetes mellitus lebih banyak berada pada 42,5\% (Tabel 3).

Tabel 4. Analisis Hubungan Efikasi Diri dengan Kepatuhan Manajemen Diri pada Pasien Diabetes Melitus

\begin{tabular}{|c|c|c|c|c|c|c|c|c|}
\hline \multirow[t]{3}{*}{ Efikasi Diri } & \multicolumn{6}{|c|}{ Kepatuhan Manajemen Diri } & \multirow{3}{*}{$\begin{array}{c}\begin{array}{c}\text { Korelasi } \\
\text { Spearman } \\
\text { Rank }\end{array} \\
\\
0,748\end{array}$} & \multirow{3}{*}{$\begin{array}{c}\text { P value } \\
0,0001\end{array}$} \\
\hline & \multicolumn{2}{|c|}{ Patuh } & \multicolumn{2}{|c|}{$\begin{array}{c}\text { Kurang } \\
\text { Patuh }\end{array}$} & \multicolumn{2}{|c|}{$\begin{array}{l}\text { Tidak } \\
\text { Patuh }\end{array}$} & & \\
\hline & $\mathrm{F}$ & $\%$ & $\mathrm{f}$ & $\%$ & $\mathrm{~F}$ & $\%$ & & \\
\hline Tinggi & 38 & 88,4 & 5 & 11,6 & 0 & 0,0 & & \\
\hline Sedang & 16 & 30,8 & 31 & 59,6 & 5 & 9,6 & & \\
\hline Rendah & 5 & 11,4 & 2 & 4,5 & 37 & 84,1 & & \\
\hline
\end{tabular}

Hasil analisis data menggunakan uji statistik Spearman Rank diperoleh nilai $\mathrm{p}$ value $0,0001(\mathrm{p}<0,05)$. Hal ini menunjukan ada hubungan yang signifikan antara efikasi diri dengan kepatuhan manajemen diri pada pasien diabetes mellitus di wilayah kerja Puskesmas Buleleng III. Pada Tabel 4 juga ditemukan nilai korelasi 0,748 yang artinya kekuatan korelasi dalam penelitian ini termasuk dalam kategori kuat dengan arah korelasi positif yang berarti hubungan kedua variable tersebut bersifat searah, dengan demikian dapat diartikan bahwa semakin tinggi efikasi diri maka tingkat kepatuhan manajemen diri pasien diabetes mellitus akan meningkat, sehingga ada keinginan untuk sembuh. Peningkatan efikasi diri diperlukan bagi pasien untuk mempertahankan perilaku yang berkelanjutan dan positif perubahan, untuk mematuhi resimen pengobatan. Efikasi diri merupakan prediktor utama dari perilaku yang dapat mempengaruhi dimulainya tugas, jumlah usaha yang dikeluarkan dalam melaksanakan tugas dan lamanya waktu orang tersebut akan memenuhi tugas (Damayanti, dkk., 2014). Efikasi diri menentukan bagaimana seseorang merasa, berpikir, memotivasi diri, dan berprilaku dari waktu ke waktu (Beckerle \& Lavin, 
2013). Menurut peneliti efikasi diri dalam penelitian ini merupakan komponen penting untuk meningkatkan kepatuhan pasien dalam memanajemen diri diabetes mellitus. Sumber-sumber terbentuknya efikasi diri melalui pengalaman individu dan pengalaman orang lain dapat meningkatkan keyakinan diri individu sehinggga mempengaruhi prilaku individu untuk melaksanakan tugas dan tujuannya dengan baik seperti kepatuhan dalam memanajemen diri.

Kepatuhan adalah sejauh mana prilaku pasien sesuai dengan ketentuan yang diberikan oleh profesional kesehatan Menurut Niven (2013). Manajemen Diri pada diabetes melitus merupakan seperangkat perilaku yang dilakukan oleh individu dengan diabetes untuk mengelola kondisi mereka, termasuk minum obat, mengatur diet, melakukan latihan fisik, pemantauan glukosa darah mandiri, dan mempertahankan perawatan kaki (Xu, et al., 2010). Menurut peneliti kepatuhan manajemen diri pada penelitian ini merupakan kepatuhan pasien dalam mengelola kondisi mereka selama memiliki penyakit diabetes mellitus. Kepatuhan manajemen diri diabetes melitus yang baik dapat mencapai keberhasilan jika individu memiliki pengetahuan dan efikasi diri untuk melakukan pengelolaan diabetes mellitus. Keberhasilan individu dalam mencapai manajemen diri yang baik akan dapat mencegah komplikasi kaki diabetik. Penelitian Harjanto, dkk (2015) menyatakan bahwa terdapat hubungan yang signifikan antara efikasi diri dengan kepatuhan pengelolaan DM tipe 2 dengan $\mathrm{p}$ $=0,001$ ( $p$ value < 0,05) dan $\mathrm{r}=0,360$. Nagler, et al (2014) efikasi diri akan membentuk keyakinan jangka panjang pasien sehingga sangat berpengaruh terhadap perilaku yang terbentuk pada pasien sehingga sangat berpengaruh terhadap perilaku yang terbentuk pada pasien dengan kondisi penyakit kronis. Efikasi diri merupakan komponen yang dapat meningkatkan manajemen diri dan hasil akhir kesehatan pasien. Peningkatan efikasi diri pasien merupakan cara yang efektif dalam mempertahankan keberlanjutan pelaksanaan manajemen diri pada pasien dengan penyakit kronis.

Penelitian ini sejalan dengan penelitian yang dilakukan oleh Yaqin, dkk (2017) mengatakan bahwa dalam penelitiannya didapatkan ada efek self efficacy training pada kedua variabel dependen yang sangat bermakna, namun jika dilihat dari hasil selisih mean dengan kelompok kontrol, variabel kepatuhan memiliki peningkatan nilai mean yang lebih besar dibandingkan variabel self efficacy. Kesimpulan 
penelitian efek self efficacy training dapat meningkatkan kepatuhan diet pasien DM melalui peningkatan self efficacy. Hasil ini juga didukung oleh peneliti Hunt, et al (2012) yang mengatakan bahwa Efikasi diri memiliki hubungan yang positif dengan manajemen diri pasien diabetes mellitus. Self care management merupakan strategi yang menjanjikan dalam hal mengobati penyakit kronis. Mengajarkan individu untuk secara aktif mengidentifikasi tantangan dan memecahkan masalah yang terkait dengan penyakit mereka (Grady\& Gough, 2015). Sutandi (2012) dalam penelitian Self Management Education (DSME) Sebagai Metode Alternatif dalam Perawatan Mandiri Pasien Diabetes melitus di Dalam Keluarga menyatakan bahwa DSME dapat digunakan sebagai metode alternatif dalam peningkatan perawatan mandiri pasien dengan diabetes melitus di rumah. DSME ini juga dapat memberikan pemahaman yang benar tentang perawatan mandiri pasien DM kepada pasien dan keluarga, penderita DM dapat hidup layaknya seperti orang lain yang sehat, yang pada akhirnya dapat meningkatkan produktifitas dan tingkat kesejahteraan keluarga dimana pasien tersebut tinggal. Handayani, dkk (2013) dalam penelitiannya Perilaku Self Management pada Pasien
Diabetes Mellitus (DM) menyatakan bahwa perilaku self management pada pasien DM di Poliklinik DM RSUD Sumedang dalam kategori baik, hal ini ditunjukkan dengan baiknya aspek prilaku diet, medikasi, olahraga dan perawatan kaki. Perilaku pasien dalam memantau kadar gula darah masuk dalam kategori sedang.

Penelitian yang telah dilakukan mengenai Efikasi Diri dengan Kepatuhan Manajemen Diri di Wilayah Kerja Puskesmas Buleleng III yang hasilnya berdasarkan indikatorindikator kuesioner General Self Efficacy (GSE) lebih banyak pada keyakinan dan kekuatan yang dimiliki, semakin tinggi efikasi diri yang dimiliki oleh individu maka akan semakin tinggi pula kepatuhan manajemen diri yang dilakukan oleh pasien diabetes mellitus, begitupun sebaliknya semakin rendah tingkat efikasi diri maka keyakinan kepatuhan manajemen dirinya juga rendah, sehingga keyakinannya untuk sembuh rendah. Indikator-indikator yang tertera dalam kuesioner DSMQ (Diabetes Self-Management

Questionnaire) responden lebih sering melakukan aktivitas fisik, pemantauan gula darah dan pengelolaan makanan. Responden meyakini bahwa dengan mengetahui kadar gula darah, melakukan pengaturan pola makan, 
serta melakukan aktivitas fisik, responden dapat mengetahui kondisinya dan dapat meningkatkan kesehatannya. Penelitian ini banyak responden yang kurang mengetahui mengenai senam diabetik, karena responden belum pernah mendapatkan informasi mengenai manfaat senam diabetik. Hasil penelitian mengatakan bahwa responden Puskesmas Buleleng III memiliki tingkat kepatuhan manajemen diri yang baik (patuh). Kepatuhan manajemen diri yang baik dapat mengurangi resiko terjadinya komplikasi yang diakibatkan oleh penyakit kronis diabetes mellitus.

\section{SIMPULAN}

Semakin tinggi efikasi diri maka tingkat kepatuhan manajemen diri pasien diabetes mellitus juga semakin tinggi, begitu sebaliknya.

\section{UCAPAN TERIMAKASIH}

Penulis ucapkan terimakasih untuk Kepala Puskesmas Buleleng III yang sudah mengizinkan penulis mengambil data penelitian di wilayah kerja Puskesmas Buleleng III.

\section{DAFTAR RUJUKAN}
Al Tera, B. H. 2011. Determinan Ketidakpatuhan Diet Penderita Diabtete Melitus Tipe 2. Skripsi. Diponegoro University.

American Diabetes Association. 2010. Diagnosis and Classification of Diabetes Mellitus. Diabetes Care, Volume 33.

Atak, N., Gurkan, T., \& Kose, K. 2010. The Effect Of Education On Knowledge, Self Management Behaviours And Self Efficacy Of Patients With Type 2 Diabetes. The Australian Journal of Advanced Nursing. 26(2), 66.

Arikunto, S. 2013. Prosedur Penelitian Suatu Pendekatan Praktik. Jakarta: Rineka Cipta.

Beckerle, C. M., \& Lavin, M. A. 2013. Association Of Self-Efficacy And Self-Care With Glycemic Control In Diabetes. Diabetes Spectrum, 26(3), 172-178.

Damayanti, S. 2017. Efektivitas (SelfEfficacy Enhancement Intervention Program (Seeip) Terhadap Efikasi Diri Manajemen Diabetes Mellitus Tipe 2. Jurnal Keperawatan Respati Yogyakarta, 4(2), 148-153.

Damayanti, S., Sitorus, R., \& Sabri, L. 2014. Hubungan Antara Spiritualitas Dan Efikasi Diri Dengan Kepatuhan Pasien Diabetes Mellitus Tipe 2 Di RS Jogja. Medika Respati, 9(4).

Grady, P. A., \& Gough, L. L. 2015. SelfManagement: A Comprehensive Approach to Management of Chronic Conditions. Revista Panamericana de Salud Pública, 37, 187-194.

Handayani, D. S., Yudianto, K., \& Kurniawan, T. 2013. Perilaku SelfManagement Pasien Diabetes Melitus (DM). Jurnal Keperawatan Padjajaran, 1(1). 
Harjonto, T., Ekwantini, R. D., \& Cahyani, C. R. 2015. Hubungan Efikasi Diri dengan Kepatuhan Pengelolaan Diabetes Melitus Tipe 2 di RSUP DR Soeradji Tirtonegoro Klaten. Skripsi. Universitas Gadjha Mada.

Hunt, C. W., Wilder, B., Steele, M. M., Grant, J. S., Pryor, E. R., \& Moneyham, L. 2012. Relationships Among Self-Efficacy, Social Support, Social Problem Solving, And SelfManagement In A Rural Sample Living With Type 2 Diabetes Mellitus. Research And Theory For Nursing Practice, 26(2), 126-141.

International Diabetes Federation (IDF). 2015. International Diabetes Federation: Diabetes ATLAS Seventh Edition. International Diabetes Federation. https://doi.org/10.1289/image.ehp.v1 $\underline{19 . \mathrm{i} 03}$.

Kementrian Kesehatan RI. 2014. Pusat Data dan Informasi. Jakarta Selatan: Kementrian Kesehatan RI.

Nagler M, Bachmann LM, Schmid P, Muller PR, Wuillemin WA. 2014. Patient Self-Management of Oral Anticoagulan with Vitamin K Antagonists in Everyday Pratice: Efficacy and Safety in a Nationwide Long-Term Prospective Cohort Study. PLoS ONE 9(4)) e95761.

Niven. 2013. Psikologi Kesehatan. Jakarta: EGC.

Nursalam. 2013. Konsep Penerapan Metode Penelitian Ilmu Keperawatan. Jakarta: Salemba Medika.
Schmitt, A., Gahr, A., Hermanns, N., Kulzer, B., Huber, J., \& Haak, T. 2013. The Diabetes Self-Management Questionnaire (DSMQ): development and evaluation of an instrument to assess diabetes self-care activities associated with glycaemic control. Health and quality of life outcomes, 11(1), 138.

Sutandi, A., \& Binawan, S. T. I. K. E. S. 2012. Self Management Education (DSME) Sebagai Metode Alternatif Dalam Perawatan Mandiri Pasien Diabetes Melitus Didalam Keluarga. Jurnal Ilmiah Widya.

Xu, Y., Pan, W., \& Liu, H. 2010. Self-management practices of Chinese Americans with type 2 diabetes. Nursing \& health sciences, 12(2), 228-234.

Yaqin, A., Niken, S., \& Dharmana, E. 2017. Efek Self Efficacy Training Terhadap Self Efficacy Dan Kepatuhan Diet Diabetesi. Ji-Kes (Jurnal Ilmu Kesehatan), 1(1). 